\title{
APPLICATION OF DIFFERENTIAL INTERFEROMETRY FOR ANALYSIS OF GROUND MOVEMENTS IN ALBANIA
}

\author{
Mentor Lamaj ${ }^{(1)}$, Neki Frashëri ${ }^{(2)}$, Salvatore Bushati ${ }^{\left({ }^{3}\right.}$, Lavdie Moisiu ${ }^{(4)}$, Gudar Beqiraj ${ }^{(5)}$, Albert Avxhi ${ }^{(6)}$ \\ ${ }^{(1)}$ Albanian Geological Service, Kavaja Str.153, Tirana, Albania, Email: lamajmentor@yahoo.com \\ ${ }^{(5)}$ Academy of Sciences of Albania, Fan S. Noli Sq.; Polytechnic Univ. Tirana; Albania, Email: nfrasheri@fti.edu.al \\ ${ }^{(4)}$ Academy of Sciences of Albania, Fan S. Noli Sq., Tirana, Albania, Email: sbushati@yahoo.com \\ ${ }^{(2)}$ Albanian Geological Service, Kavaja Str.153, Tirana, Albania , Email: ledimoisiu@yahoo.com \\ ${ }^{(6)}$ Academy of Sciences of Albania, Fan S. Noli Sq., Tirana, Albania, Email: gudar.beqiraj@yahoo.com \\ (3) Albanian Geological Service, Kavaja Str.153, Tirana, Albania ,Email: aavxhi@yahoo.com
}

\begin{abstract}
Albanian territory is experiencing geomorphological changes that are impacting both the environment and human activities. The tectonic zone of PreAdriatic Depression is one of most touched areas by the erosion, landslides and movement of the Adriantic Sea shoreline. Intense human activities are going on in hilly ranges parallel to the sea shore that are partly composed from lousy sandstone and subject to catastrophic landslides. Complicated geomorphologic phenomena are observed during the sea shore characterised by significant sea transgression in typically accumulative areas. For several years we have studied these phenomena using satellite imagery, using free archives of LANDSAT, SAR ERS and ENVISAT. In the paper we present some results obtained recently using SAR images.
\end{abstract}

\section{REVIEW OF GEOMORPHOLOGIC PHENOMENA IN ALBANIAN LOWLANDS}

Northern half of Albanian western territory - the PreAdriatic Depression tectonic zone is composed by lowlands and hilly ranges, bordered in the West by Adriatic Sea. Geologic formations are recent Quaternary deposits as lousy sandstone, conglomerates and clay; areas that were seaside in antiquity today are situated 10-15 km inshore. Important rivers have contributed for the development of lowlands - Drini and Mati in north and Shkumbini, Semani and Vjosa in south.

From several decades economic activities are developed in Adriatic shore areas. During last twenty years there is a significant change in the pattern of these activities, with increase of buildings in hilly ranges. Important is the fact that recent activities are developed with no control on their environment impact. As result, activities near the beach are impacted by sea transgression while in hilly ranges there is an increase of landslides; all this had important negative impact in human activities [1].

False color LANDSAT images in Fig.1 present respectively the southern (a) and the northern (b) sections of Albanian lowlands. Images are produced combining NIR bands from three different years 1972-
1986-2002 as a single RGB image, where sea regression and transgresion areas are visible in respectively Blue and Red colors [2][3].

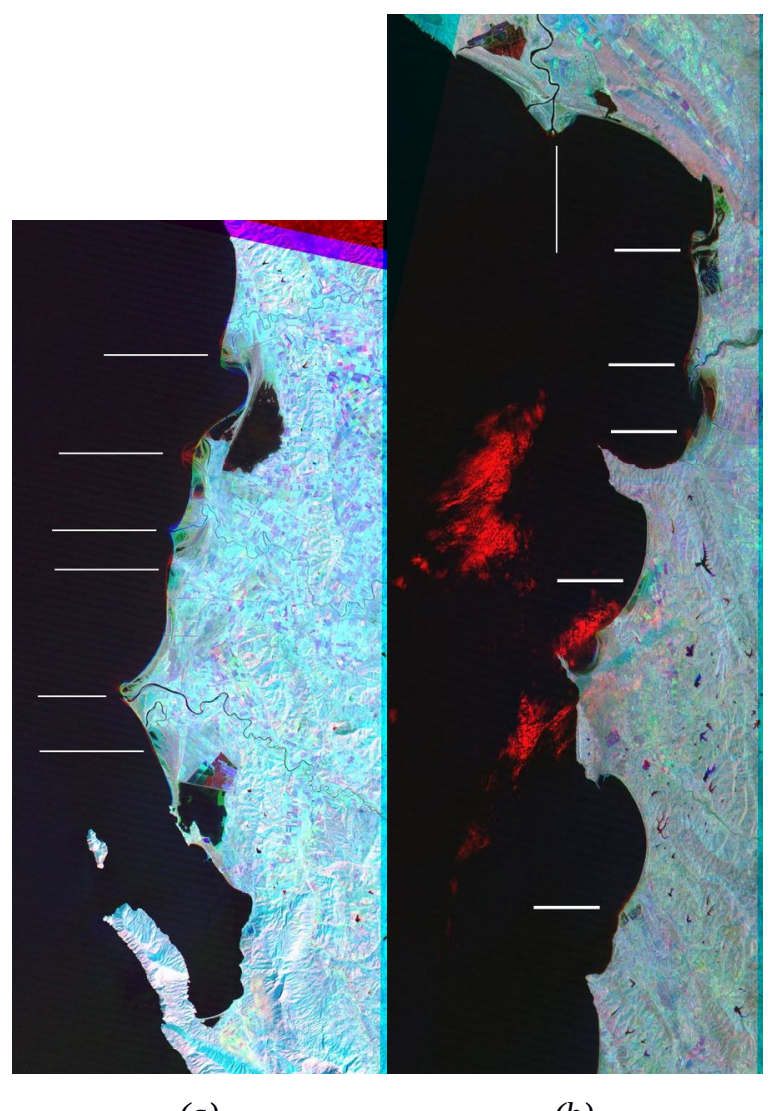

(a)

(b)

Figure 1. Lowlands from NIR bands of LANDSAT

The study was organized in two "layers". The first in the focus was the area between the delta of Shkumbini River and the Durresi city. For this area the SqueeSAR ${ }^{\mathrm{TM}}$ software was used and multimage SAR calculations were carried out by the company TRE in Milano, Italy. Traditional two-image interferograms were calculated for both segments of lowlands presented in Fig. 1.

In Fig. 2 a typical landslide is presented, which 
happened in 2007 in Synej village. Geological formations of these hills are lousy sandstone and their structure is disturbed from human activities. The sliding mass was separated from the hill creating a deep "canyon" that now is used as a road.

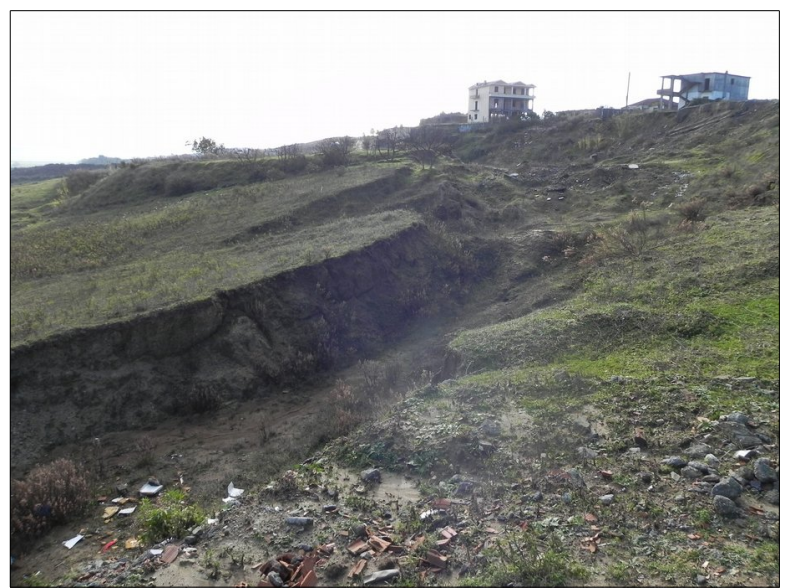

Figure 2. Landslide in Synej

In Fig. 3 a section of Adriatic beach in Semani delta area is presented, showing a water tower now situated offshore. The discussion for causes of this sea transgression considers the sea erosion and land subsidence.

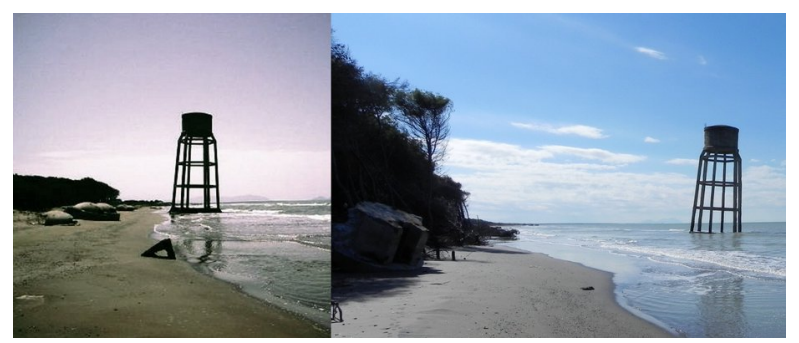

$(a-2007$ [4])

$(b-2010)$

Figure 3. Sea transgression in Semani area

After analysing traditional images from the field and satellites LANDSAT, the attention was focused in SAR images and interferometry techniques as a tool to evaluate vertical movements of the ground with centimetric precision. The methodology we used is described in details in the next section.

\section{USED SAR METODOLOGY}

Two methods lies of SAR differential interferometry were used: surface interferometry and scatterers-based pointwise interferometry. EOLISA software [5] was used to access the database and select pair of images for both southern and northern segments of lowlands.

For surface interferograms formally suitable pairs of ASAR images were obtained from ESA in framework of a small project "Seman 14921" in 2013. The aim was to select pairs with the largest time difference possible. For the southern segment two pairs of IMS images were selected for dates 2003/07/04 : 2007/02/23 with baseline 40m and 2003/03/21 : 2007/11/30 with baseline 746m.

For the northern segment only one pair of IMS images was selected for dates 2003/03/21 : 2004/11/05 with baseline $100 \mathrm{~m}$. Also ERS images with larger time difference were downloaded but problems with orbit files forbid their use.

The calculation procedure [6] was tested with ASAR IMS images from L'Aquila earthquake of 2009. Two software packages were tested, firstly RAT \& IDIOT [7] and finally ESA NEST [8].

Two final interferograms were calculated using ESA NEST software with pairs of dates 2003/07/04 : 2007/02/23 and 2003/03/21 : 2007/02/23. The image of 2007/02/23 was not used because of related orbit file problem. Both wrapped and unwrapped interferograms were calculated. Interpretation of results is presented in the next section.

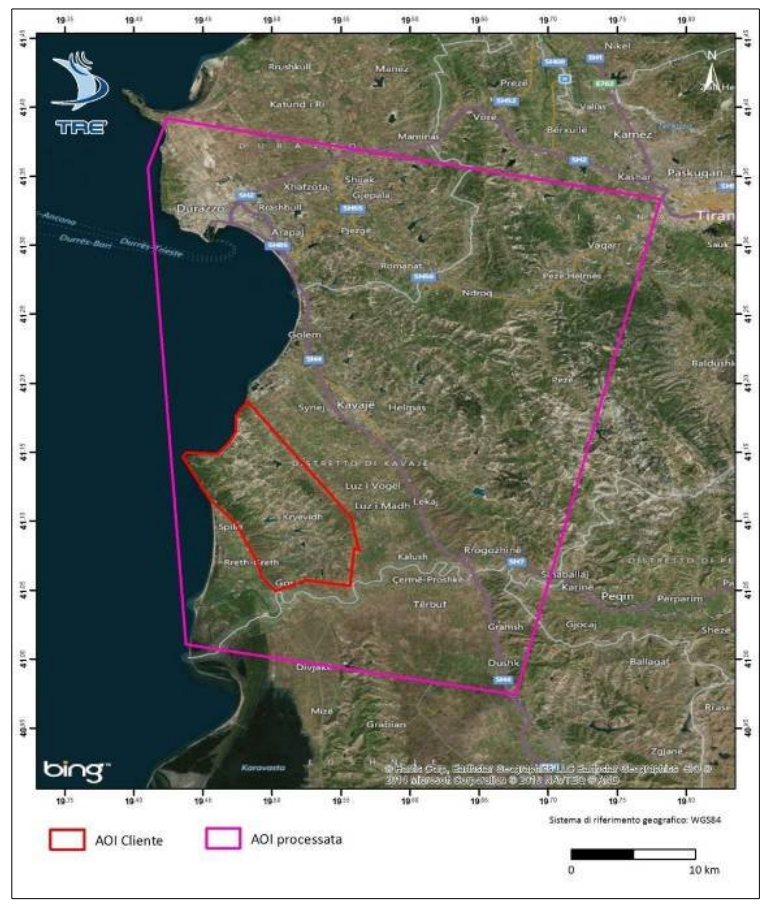

Figure 4. Area studied with SqueeSAR.

Pointwise scatterers interferograms were calculated with the aid of the specialized company TRE (Milano, Italy) using the software package SqueeSAR ${ }^{\mathrm{TM}}[9-21]$. The studied area is shown in Fig. 4.

Two sets of ERS images were used for the period 1992 2000, 31 images of upward pass and 50 images of 
download pass. Time interval between two successive images was 35 days. A total of 11.657 scatterer points was identified. Both horizontal and vertical velocities of scatterer points were calculated from Line-of-Sight (LOS) relative displacements.

\section{RESULTS OF POINT INTERFEROGRAMS}

Several small areas were selected from the area covered by SqueeSAR ${ }^{\mathrm{TM}}$ for detailled analysis (Fig. 5):

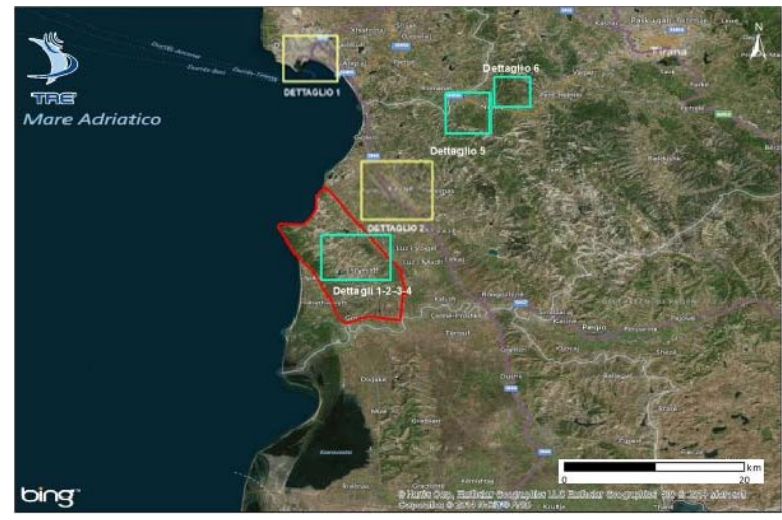

Figure 5. Analysed areas from SqueeSAR ${ }^{T M}$

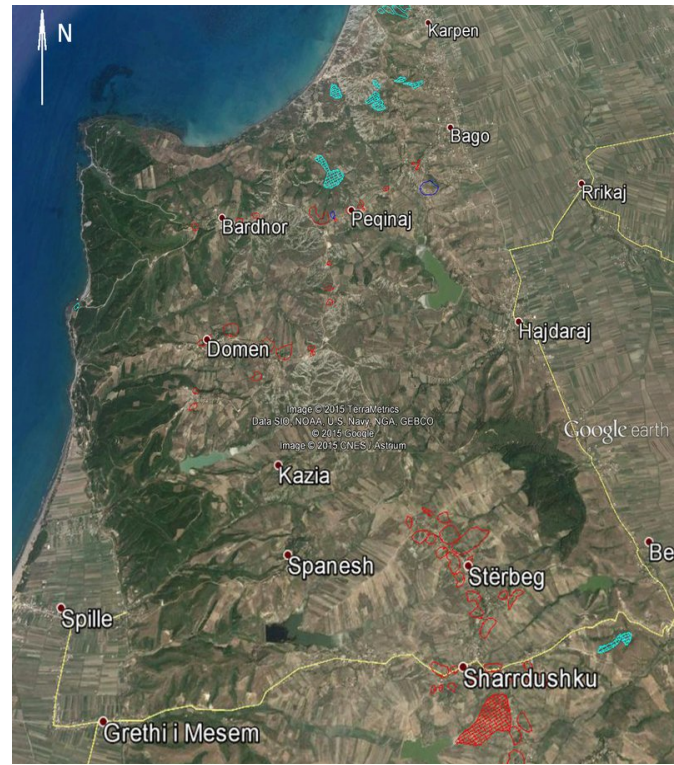

Figure 6. Landslides identified through field work

In focus was the most critical section of this area situated in the hilly range bordered with red at the center of the image in Fig. 5. Numerous landslides were identified in this section using traditional methods during geological field work (Fig. 6). Values of yearly averages of displacement velocities in LOS are presented in Fig. 7:

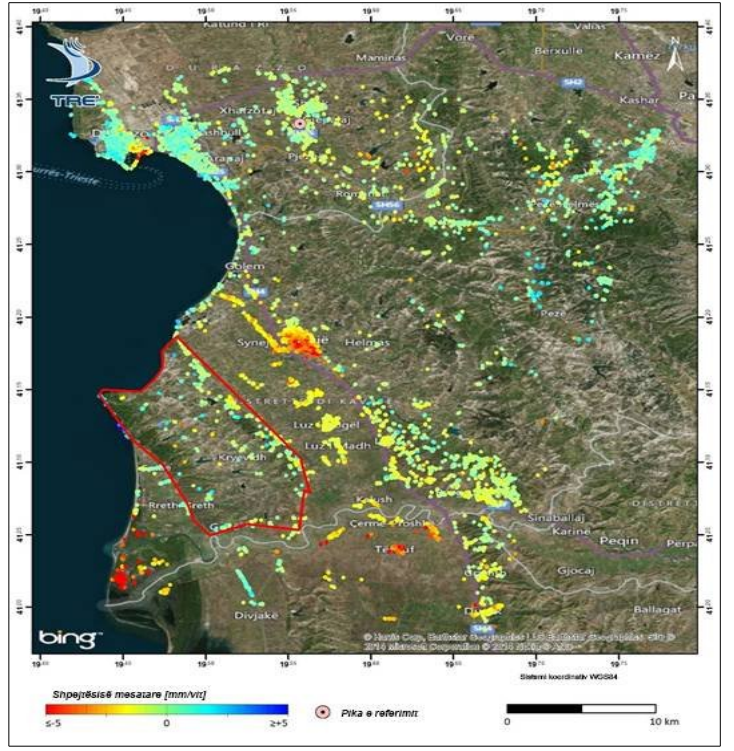

Figure 7. Yearly averages of velocities in LOS

Identified scatterer points were located mainly in urban areas and those with scattered or without vegetation. Significant displacements are in Kavaja city, delta of Shkumbini River and the village of Terbufi. Based on LOS displacements and orbital parameters the vertical and horizontal displacement velocities were calculated (Fig. 8 and Fig. 9).

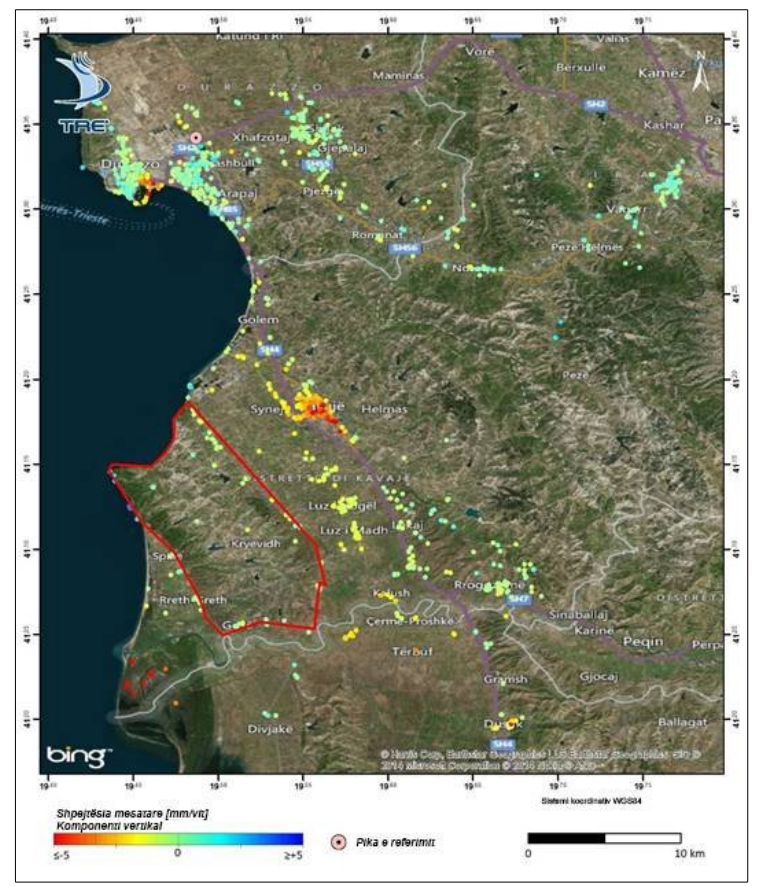

Figure 8. Yearly averages of vertical velocities 


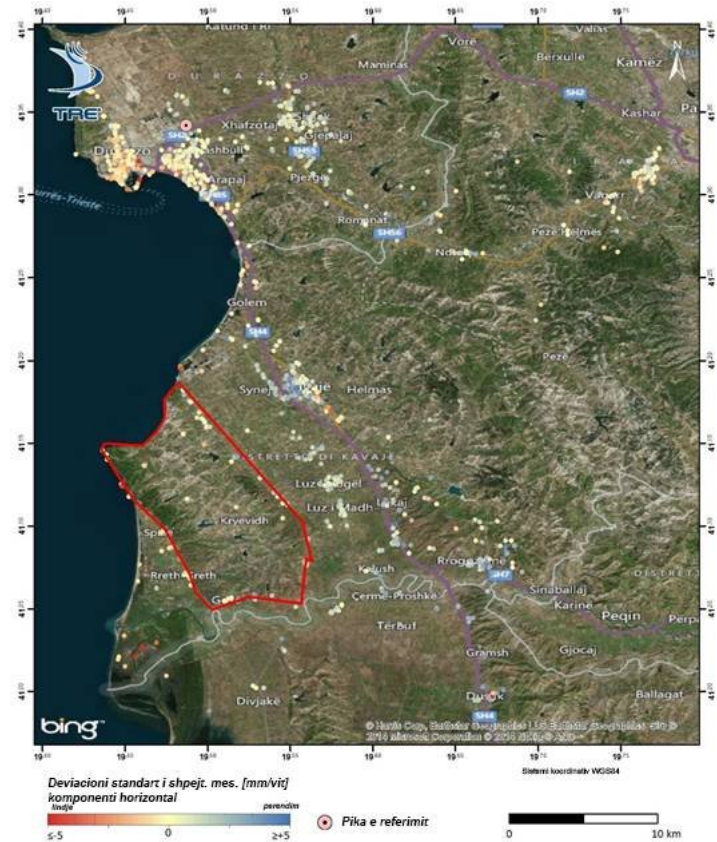

Figure 9. Yearly averages of horizontal E-W velocities

The area bordered with red line has been subject to intense field work for identification of landslides and field results were compared with SqueeSAR ${ }^{\mathrm{TM}}$ data. From the analysis of satellite data some new landslide sites were identified in villages Sterbeg (Y - 4374 489, X - 4554 987; Fig. 10), Kazie-1 (Y - 4373 673, X - 45 55 103; Fig.11) and Kazie-2 (Y - 4373 617, X - 4555 199; Fig. 12).

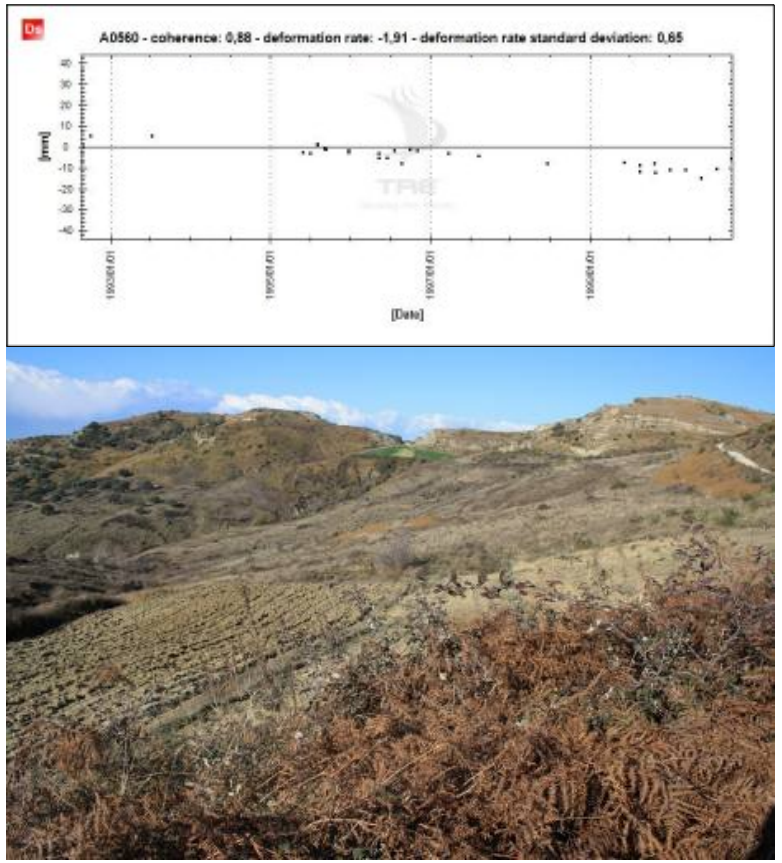

Figure 10. Landslide in Sterbeg

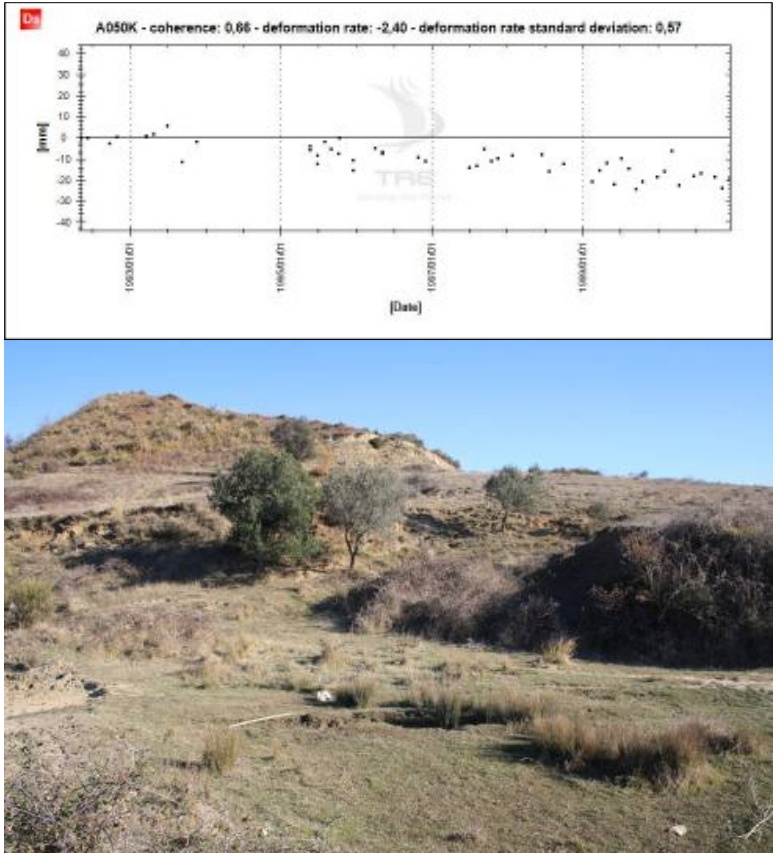

Figure 11. Landslide in Kazie-1
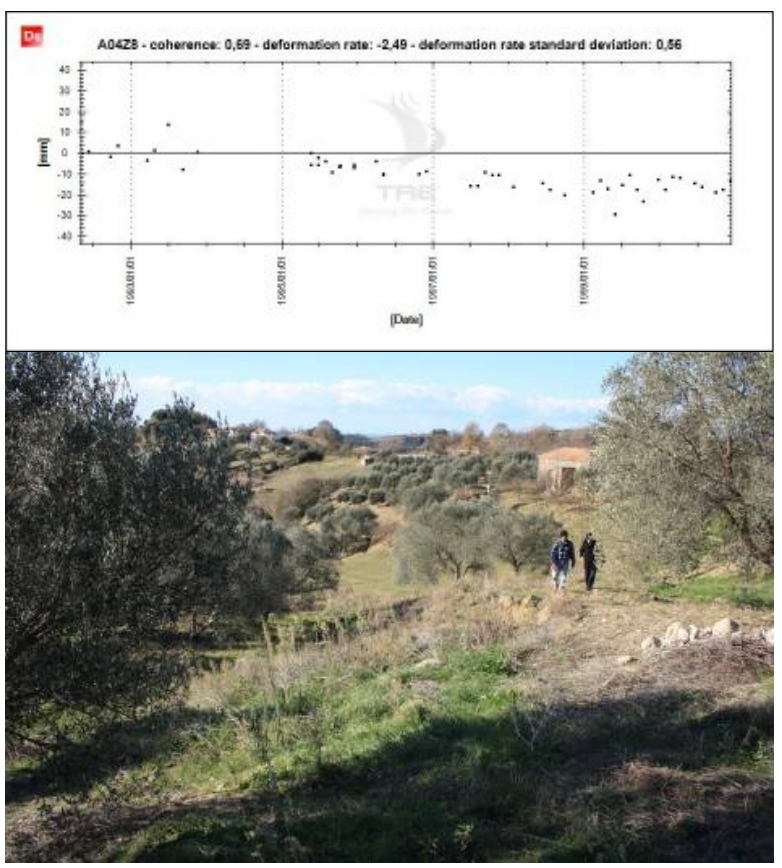

Figure 11. Landslide in Kazie-2

\section{RESULTS OF SURFACE INTERFEROGRAMS}

First differential interferograms were calculated for the southern segment of PreAdriatic Depression lowlands, shown in Fig. 13. The coherence is shown in Fig. 14. Few fringes are distinguished, which cannot be directly interpreted as vertical displacements of the ground. Most of them probably are result of vegetation variations, mostly in mountainous areas [22]. Only fringes in the seashore in points $\mathrm{B}$ and $\mathrm{C}$ there are 
formally correlated with sea regression and transgression (see also [24]). The point A represents a wetland near she seashore. In Polis mountain range vegetation variation is already identified through Landsat images.

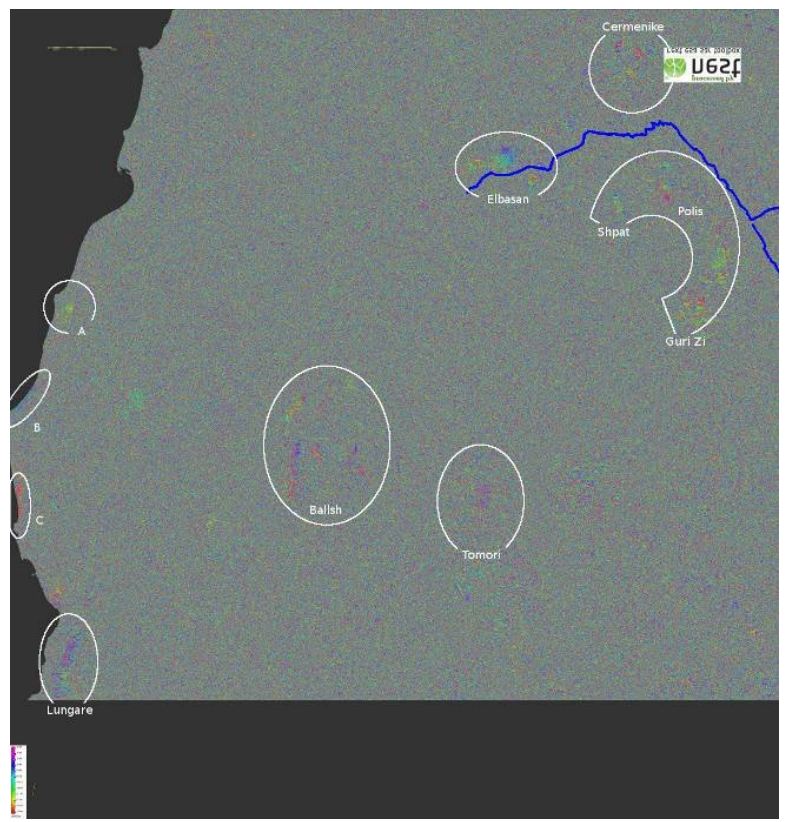

Figure 13. Souuthern differential interferogram

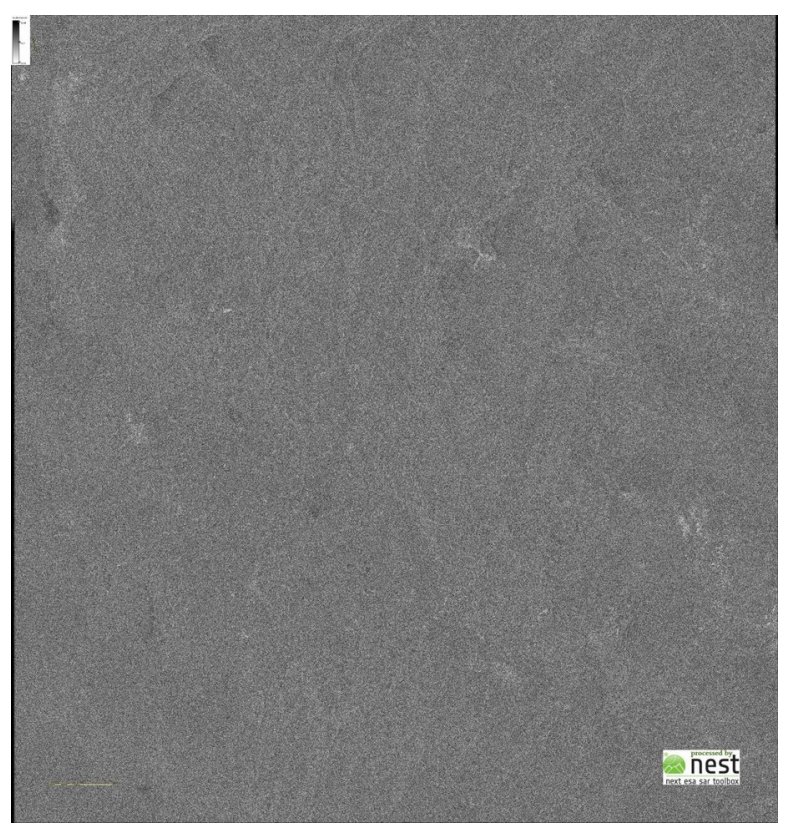

Figure 13. Souuthern interferogram coherence

The unwrapped interferogram is shown in Fig. 15, the image was filtered with Gausian filter and a number of straight features were identified that correlate with the mountain ranges, probably tectonic fractures [23].

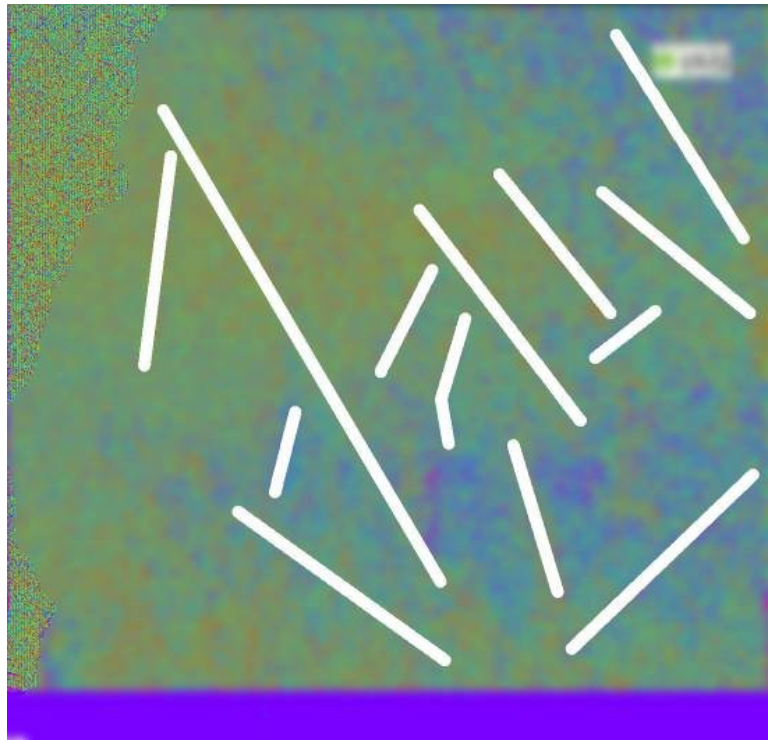

Figure 15. Unwrapped filtered interferogram

The differential interferogram of northern segment of PreAdriatic Depression lowlands is shown in Fig. 16.

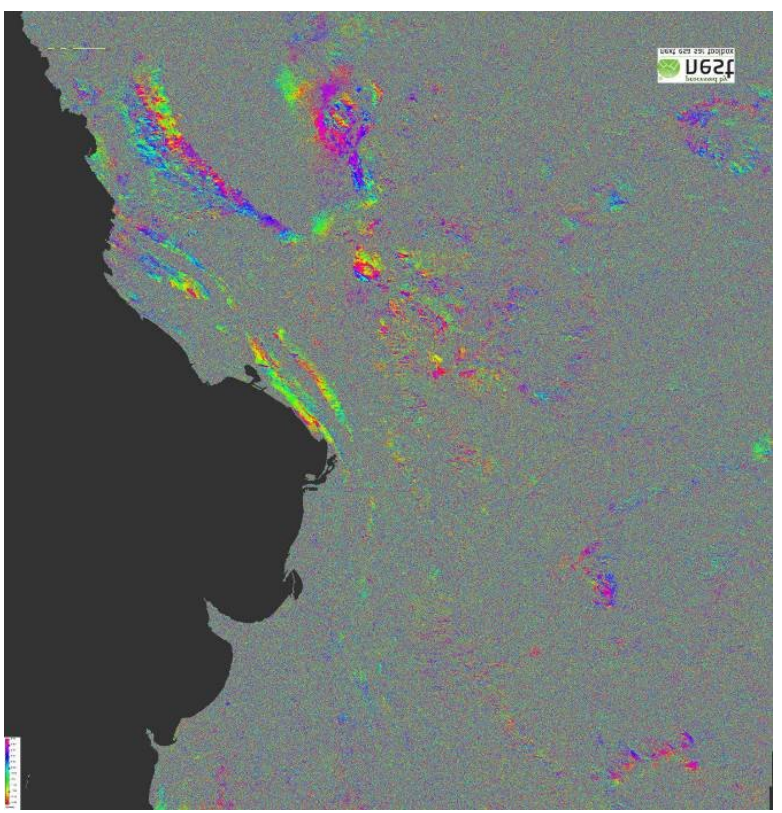

Figure 16. Northern differential interferogram

Correlation of fringes with mountain ranges is much more vizible compared with the southern case. Again their interpretation is towards vegetation variations. Nevertheless weak signs of correlation with the slow but huge landslide of Ragami in shores of Vau Dejes Hydropower Lake are identified (Fig. 17). 


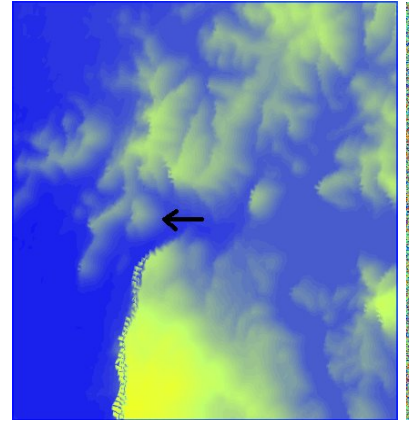

(a)

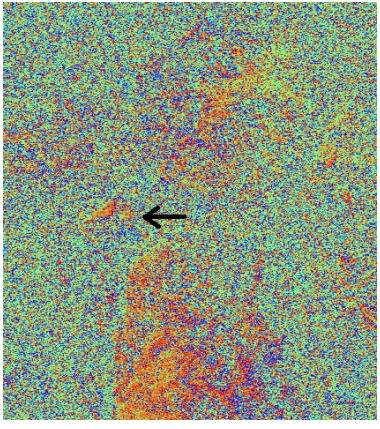

(b)
Figure 17. DEM [25] (a) and interferogram (b) of Ragami landslide

\section{CONCLUSIONS}

Field observations in PreAdriatic Depression lowlands have identified that residnetial building constructions in the Semani area are situated over a dynamic terrain in process of creation. Consequently part of buildings are destroyed as result of a complex of factors that include movements of deltas, possible subsidence of the ground evolved in several decades, and catastrophic landslides.

Moreover, gaps in scientific knowledge regarding local ecosystem processes and inappropriate policies have been a continuous obstacle for appropriate environmental solutions [26].

LANDSAT images helped the identification of areas where the sea shore line has moved mainly inland, but the images resolution is not sufficient for a detailed analysis of the shore and landslides in hilly areas. Radar imagery ERS and ENVISAT have resolution similar to LANDSAT but offer the possibility of evaluation in surface and pointwise of vertical movement of the ground in areas that are not disturbed by vegetation variations.

SqueeSART ${ }^{\mathrm{TM}}$ and NEST software was used to develop interferograms. Multi-image pointwise interferograms built by the company TRE using SqueeSAR ${ }^{\mathrm{TM}}$ for a limited segment of lowlands permitted the identification of ground displacements related with landslides including unknown landslides in a studied area which has been carefully scanned through field works. Subsidence was identified in part of urban areas and especially in the delta of Shkumbini River. Periodic use of pointwise interferograms for the whole territory would help to identify unknown existing and potential landslides and permit the undertaking of appropriate measures for mitigation of negative impact.

A minimal number of SAR images were used for surface differential interferograms built with NEST software, which gave few fringes in hilly and mountainous ranges and supposed to be caused by vegetation variations. Only few weak fringes potentially generated by beaches vertical movements and one case of a massive but slow landslide are identified.

The conclusion is simple - despite the complexity of Albanian terrain evolution including rapid urban expansion and significant vegetation variations, SAR interferograms gave the proof that are a good tool to analyze existing and potential landslides, as well as areas with significant vertical movements of the ground in this concrete territory. Application of Remote Sensing technique, using SAR intereferograms for the whole territory of Albania is a need for a better management of catastrophic phenomena.

\section{REFERENCES}

1. Aliaj Sh., Baldassare G., Shkupi D. (2001). Quaternary subsidence zones in Albania: some case studies. Bull Eng Geol Env 59:313-318 Springer Verlag

2. Frasheri N., Beqiraj G., Bushati S., Frasheri A., Taushani E. (2014). Remote Sensing Analysis of the Adriatic Shoreline Movements. International Scientific Conference Integrated Coastal Zone Management in the Adriatic Sea, Institute of Marine Biology, Kotor, Montenegro 29 September - 1 October 2014.

3. USGS ( 12/30/2014) Landsat Data Access. http://landsat.usgs.gov/Landsat_Search_and_Dow nload.php

4. Albaviator (2007) Seman (photo). https://www.flickr.com/photos/albanianairforce/86 9073392

5. ESA Earth Online 2000 - 2015. EOLi - ESA's Link to Earth Observation. https://earth.esa.int/web/guest/eoli

6. Osmanoglu B. (2010). Tutorial: Processing Envisat SAR Interferograms with ADORE. http://www.osmanoglu.org/adore-doris-downloads

7. Reigber A., Erten E., Guillaso S., Hellw O. (2007) IDIOT: a free and easy-to-use software tool for dinsar analysis. Proc. 'Envisat Symposium 2007', Montreux, Switzerland 23-27 April.

8. ESA 2000 - 2015. NEST - Next ESA SAR Toolbox. https://earth.esa.int/web/nest/home

9. Allievi J., Bonsignore F., Cespa S., Colesanti C., Colombo D., Ferretti A., Morelli M., Pistocchi M. (2003) Analisi di fenomeni di deformazione superficiale sul territorio dell'Autorità dei Bacini Romagnoli a partire da serie di dati radar satellitari elaborati con la tecnica dei diffusori permanenti. 
Atti della $7 \wedge$ Conferenza Nazionale ASITA, Verona, 28-31 ottobre, 45-50.

10. Allievi J., Ambrosi C., Ceriani M., Colesanti C., Crosta G.B., Ferretti A., Fossati D. (2003) Monitoring slow mass movements with the Permanent Scatterers technique. Geoscience and Remote Sensing Symposium, IGARSS '03. Proceedings. 2003 IEEE International, Volume: 1

11. Bottero D., Poggi F., Cespa S. (2006) Il monitoraggio SATELLITARE. Primi risultati in Liguria della sperimentazione dell'utilizzo della tecnica PSInSAR ${ }^{\mathrm{TM}}$. Quarry \& Construction, ottobre 2006.

12. Catani F. Colombo D. Farina P. Fumagalli A. Kukavicic M. Marks F. Menduni G. Moretti S. () Utilizzo di dati telerilevati nella mappatura e nel monitoraggio dei fenomeni franosi e nell'analisi della suscettibilità da frana. Giornale di Geologia Applicata 3 (2006) 173-180

13. Colesanti, C.; Ferretti, A.; Prati, C.; Perissin, D.; Rocca, F., (2003) ERS-ENVISAT permanent scatterers interferometry. Geoscience and Remote Sensing Symposium, IGARSS'03. Proceedings. IEEE International, vol.2, 21-25 July 2003 Pages: 1130 - 1132

14. Colesanti C., Ferretti A., Prati C., Rocca F. (2003) Monitoring landslides and tectonic motions with the Permanent Scatterers Technique. 2002. Elsevier, Engineering Geology vol.68, 3-14

15. Farina P., Colombo D., Fumagalli A., Marks F., Moretti S. (2006) Permanent Scatterers for landslide investigations: outcomes from the ESASLAM project. Elsevier, Engineering Geology vol.88, 3-4

16. Ferretti A., Fumagalli A., Novali F., Prati C., Rocca F., Rucci, A. (2011) A New Algorithm for Processing Interferometric Data-Stacks: SqueeSAR. IEEE Transactions on Geoscience and Remote Sensing, vol.49, issue 9.

17. Ferretti A., Prati C., Rocca F. (2001) Permanent Scatterers in SAR Interferometry. IEEE Transactions on Geoscience and Remote Sensing, vol.39 issue 1.

18. Giannico C. ( 2013) Il monitoraggio satellitare: nuova frontiera per la studio di strutture e infrastrutture. 2013. Il Giornale dell'Ingegnere, N. 10 - Ottobre .

19. Manunta P., Brugioni M., Casagli N., Colombo D., Deflorio A.M. Farina P., Ferretti A., Gontier E., Graf K., Haeberle J., Lateltin O., Meloni E., Mayoraz R., Montini G. Moretti S., Paganini M., Palazzo F., Spina D., Sulli L., Strozzi T. (2003) SLAM, a service for landslide monitoring based on EO-data. Proc. of FRINGE 2003 Workshop, Frascati, Italy, 1 - 5 December 2003 (ESA SP-550, June 2004).

20. Tamburini A., Del Conte S., Larini G., Lopardo L., Malaguti C., Vescovi P. (2011) Application of SqueeSAR ${ }^{\mathrm{TM}}$ to the characterization of deep seated gravitational slope deformations: the Berceto case study (Parma, Italy). Proceedings of the Second World Landslide Forum, 3-7 October Rome.

21. Urbisci S., Allievi J., Cespa S., Gervasi C. (2005) Elaborazione di dati radar satellitari per la Carta del Rischio delPatrimonio Culturale della Lombardia. ASITA 2005, 15-18 Novembre, Catania, Italia; Pagine 1-6.

22. Ruiz A.M., Sousa J., Hanssen R.F., Perski Z., Gil A.J., Bastos L., Galindo-Zaldívar J. (2008). Measurement of ground subsidence in the Granada area (Southern Spain) using PS-InSAR. IX International Congress on Geomatics and Surveying Engineering, Valencia.

23. Favretto A, Geletti R, Civile D. (2013). Remote Sensing as a Preliminary Analysis for the Detection of Active Tectonic Structures: an Application to the Albanian Orogenic System. GEOADRIA 18/2, 97-111

24. Avallone A., Zollo A. (1999). Subsidence of Campi Flegrei (Italy) detected by SAR. Geophysical Research Letters, vol. 26, no. 15

25. USGS (Sept 30, 2010) Shuttle Radar Topography Mission. http://srtm.usgs.gov/index.php

26. Moisiu L., Kapsimalis V., Durmishi Ç., Anagnostou C. (2014) Application of DPSIR Framework to a Mediterranean Transitional Water Body: The Butrint Lagoon, SW Albania. AJNTS, Academy of Sciences of Albania Vol.1 